\title{
The Disintegration of the Democratic Eastern Federation and the Demise of its Supporters 1885- 1896 and the Poems of Ossian
}

\author{
By Kathleen Ann O’Donnell*
}

\begin{abstract}
The founder of the Democratic Eastern Federation Panayiotis Panas and main translator of "The Poems of Ossian" published this poetry between 1885 and 1890. Are these poems relevant to historical events of the time and do they show similarities between the magnanimity of the Celtic heroes and those who tried to bring peace and harmony through the Democratic Eastern Federation? In 1885, "Dar-thula" was republished when disunity began in the Balkans. Under the Treaty of Berlin (18781881) offspring of the German, Russian and English monarchy ruled in the Balkans. War broke out between Serbs and Bulgarians when Bulgaria's monarch attempted to enlarge its territory. Under threat of another blockade by England, Greece was warned not to assist the Serbs. The translation of the "Death of Cuchullin" by Panas is prophetic. It represents both the death of any unity in the area and the demise of its supporters of the association.
\end{abstract}

Keywords: Cultural history, Egypt, Monarchy, the poems of Ossian, 19th century Greek journalists.

The Democratic Eastern Federation or the Rigas Association (Stavropoulou 1987) was an organisation set up by scholars in South Eastern Europe: including Athens, Bucharest and Constantinople (Hasiotis 2001) in an attempt to forge a peaceful solution to the threat of Western imperialistic division of the Ottoman Empire. Its tenets were based on Ancient Greek democracy and those of the French Revolution (1793) which form the basis of the Constitution and Declaration of Human Rights written by the GreekRumanian scholar and first promartyr of the Greek Revolution, Rigas Velestinis. His intention had been to form an Anatolian Federation which would include people of all faiths to combat and overthrow the tyrannous rule of the Sultan and to form republics built on democratic principles of equality and justice. Rigas believed that bad government does not come from an ethnic, race or creed but from a lack of good laws. His future republic would be built on the principles of equality and justice (Cordahi 2000).

"The law must be the first and only chief leader of the country". (Korthatos 1973)

The vision of a confederation by Rigas was not a question which could have been considered "Balkan" since it was destined to stretch beyond the

${ }^{*}$ Independent Scholar, British School at Athens, Greece. 
European continent into Anatolian territories the term "Balkan" not being in use in the nineteenth century. (Svolopoulos 2000) For example, the exiled antimonarchist poet and democrat Alexander Soutsos carved the words "Long Live the Greek Constitution up to the Egyptian pyramids" on a pyramid in Cairo in 1859 (Korthatos 1983). The confederation would embrace people in the Ottoman provinces of South East Europe, and Egypt (Velesinlis 1994). Hellenism excluded racial, ethnic or religious connotations, the only supremacy being recognised as a Greek entity was that of the language as Modern Greek was the most widely spoken language in the zone (Mavromoustakou 1998). Nationalism and monarchism was eschewed in preference to a confederation run on democratic lines. The DEF did not support Russian aggression in the Balkans. Members of the Rigas Association or the DEF were also supporters of the Paris Commune whose main adherents were Proudhonians. Heralds of socialism, they supported the working people.

The founder of the DEF in Athens (1868) was Panayiotis Panas, a Kephalonian scholar and journalist who had resided in Rumania and Alexandria. His colleague, a scholar, journalist and headmaster, Thomas Paschides, from Epiros, (an Ottoman province), was head of the organisation in Bucharest (Hasiotis 2001). Panas had fought, (Stavropoulou 1987) together with Paschides in the uprising in Thessaly in 1856 (Hadziphotis 1974). Another revolutionary Dionyssius Oikonomopoulos, born in Zakinthos, whose parents were from Smyrna, had volunteered in the Spartianon Division in the Thessaly uprising, which was put down by the French and English. After completing his speciality in medicine in Athens, Oikonopoulos moved to Alexandria in 1861. He became known as the father of Greek-Egyptian journalism (Nikitaridis 2015). His collaborators there were Ferdinand Oddi and Spiro Pherantinos, Kephalonian classmates of Panas.

Panas moved to Alexandria in 1865 where he published the newspaper "The Egyptian Eagle" in collaboration with Pherentinos (Stavropoulou 1987). In 1872, Pherentinos published his long epic poem entitled "Ode to the erecting of the Statue of Mohammid Ali" (Pherentinos 1872). Mohammid Ali, an Albanian Muslim, was the first Viceroy of Egypt whose grandson Ismail was determined to take control as leader of Egypt although his uncle Prince Halim Pasha was also a contender for the throne (Ross 1912). Halim Pasha, the son of Muhammid Ali, represented a threat to Ismail's ambition of having his son become heir. While Ismail's mother was the sister of the Sultan (Isma'il Pasha n.d.), Halim's mother, a Bedouin, was the last wife of Muhammid Ali. More than all other possible leaders, Halim Pasha cared about his people (Ross 1912) but his rapacious nephew, Ismail desired his son to inherit his throne (Gordon Duff 1969) which he bought by lavishing gifts worth $\$ 5$ million on the Sultan to buy the Khediveship (Imperial Firman of 27 May 1866 2012), at the expense of the Egyptian people, which he succeed in doing in 1866.

In 1865, Panas published his extract from "Temora Book IV" entitled "The Dream of Cathmor and Sul-malla", in his book of poetry "Memnon", published and distributed to towns along the Nile by Nile Press, owned by Oddi. This book also included the poem "Daughter of Lekavitos", which contained a 
dedication taken from "Dar-thula", published in the British Protectorate of Kephalonia in 1862 (Stavropoulou 1987). Prince Halim, whose popularity among the people had been destroyed by Ismail (Gordon Duff 1969), was in danger and had to flee Egypt when he claimed his rights as the rightful inheritor of the throne. Both the classmate and colleague of Panas, Ferdinand Oddi and Panas's fellow fighter in the Thessaly uprising in 1856, D. Oikonomopoulos, saved his life by helping Halim escape from Alexandria to Istanbul in 1866 (Hadziphotis 1999).

The extract from "Temora IV" entitled "The Dream of Cathmor and Sulmalla" is a comparison of two brothers, Cairbar, a usurper and tyrant and Cathmor, a just and dedicated warrior (Panas 1865). It is an implicit reference to Ismail and Halim. The symbolism of Panas's extract from "The Dream of Cathmor and Sulmalla", is even more pronounced when in 1875, the Khedive Ismail (Cairbar) who governed Egypt in the name of the Ottoman Empire made it known to Alphonse de Rothschild in Paris that he wished to sell a substantial amount of his shares in the Suez Canal. The Suez Canal had been built by the French under Ferdinand de Lesseps and was completed in 1869 (Lottman 1994). It is noteworthy that more than 20,000 Egyptians worked in corves, building the canal by hand, under the whip (Ross 1912). Alphonse alerted his cousin, Lionel, in London of this offer who, in turn, came into contact with Disraeli, the Prime Minister (Lottman 1994). In November, 1976, Disraeli guaranteed the loan of four million pounds sterling from Lionel Rothschild to the British Government pending its reconvening in February, 1876. In 1875, the net profit made from the Canal was seven million pounds sterling most of which went to the British after Ismail disposed of Egyptian shares worth 100 million francs to Lord Rothschild, who in turn sold them with interest to the British Government under Disraeli (Bouvier 1967). Disraeli gave his word in the House of Commons to the effect that this transaction would secure peace in the region (The Sun 1876). Rothschild went on to loan the Khedive more money which was guaranteed by control of 151 hectares under Rothschild, of the best part of land on the Nile Delta (Bouvier 1967). This was an example of the Egyptian people being defrauded at the hands of a despot, whose exploitation by Western monarchy had been foreseen by Rigas.

In Constantinople, there was a Turkish part of the D.E.F., probably headed by Midhat Pasha, the Grand Vizier (1876) (Hasiotis 2001). His new reforms to bring equality to all subjects under Ottoman control were given support by Prince Halim Pasha, (Cathmor) son of Muhamid Ali, first Khedive of Egypt (Zurcher 1984). Halim Pasha was chosen as Khedive of Egypt after the Sultan dismissed Ismail in 1879, which was reported as far away as Australia (Bendigo Advertiser 1879) but Western Powers objected, insisting that Tewfik, son of Ismail, become the next Khedive. The Sultan would make several more requests insisting that Halim become Khedive but to no avail as the Western Powers were adamant in retaining Tewfik as Khedive (Baring 1908). Panas realised that the Great Powers were trying to preserve the dwindling Ottoman Empire to serve their own interests. He saw that the real threat to the DEF was the Europeans - the Great Powers (Stavropoulou 1987). 
Western monarchy had imposed its kingdoms on former Ottoman territory twice in Greece in the 1830s and again in 1864, then in Rumania two years later. In 1879 the Russian Tsar placed Alexander of Battenberg as Prince of a small principality (Bulgaria) in Eastern Roumalia while the Hapsburgs occupied Bosnia-Herzegovina in 1878. England obtained Cyprus in the same year. Prince Charles (Hohenzollen) became King Carol I of Rumania in 1881. In Serbia Prince Milan Obrenovich became King of Serbia in 1882 (Stavrianos 2000).

To counter the takeover of Western powers under monarchy, journalists who believed in the aims of the DEF contributed to several periodicals in Greece and Rumania. These journals exposed injustices, which its contributors hoped to rectify. Many of these injustices coincided with the translations of "The Poems of Ossian". The Athenian "Rambagas", (1878-89) a most fanatically democratic and literary forward-looking journal attempted to open the eyes of the people, both politically and socially, by exposing the dirty scandalous social life of the court and its minions while emphasising, at the same time, their indifference to serious problems that were being faced by the kingdom. It kept up its continual fight against the monarchy and the incompetent government. Other contributors included Achilles Paraschos, the poet, the M.P. for Attica and leading judge, Aristedes Oikonomos as well as the first socialist M.P. and Public Prosecutor, Rokkos Hoidas (Stamelos 1982).

Aristedes Oikonomos (1835-1890) was a Greek Lawyer. He became a judge on Syros, where he practised until he taught Political Economy at Athens University. He was judge of the Court of the First Instance, the Court of Appeal and Public Prosecutor. He published the periodical "Economic Review" from 1873-1890. He was elected as an independent Member of Parliament in 1879 and in 1885 (Aristeidis Oikonomos 2010).

The first socialist M.P. and Public Prosecutor, Rokkos Hoidas was elected Member of Parliament for Kephalonia in 1875. His Kephalonian father, Dimitris, had fought under Alexander Ipsilantis in the Battle of Dragatsini on 24 February, 1821. After being elected into Parliament in 1885 for Athens, Hoidas's speeches in Parliament were catapulted against the palace, sycophants and former democrats, who were in keeping with the monarchy, such as Harilou Trikoupis (Loukatos 1984).

Using the pseudonym "Aloupis", Panas, whose early satire was greatly influenced by Alexander Soutsos, published articles in "Rambagas" (Stavropoulou 1987). Its regular attacks, with its biting satire, on the Danish monarch and representatives of the Great Powers, resulted in its owners, the Cycladic poet Cleanthese Triantaphillos, also named Rigas, the second promartyr of democracy, and Vlassis Gavriialidis, a scholar from Constantinople, being imprisoned after its first publication. In 1881, Triantaphillos was imprisoned again, without trial, for writing the poem "King". This poem describes how the monarch was enjoying entertainment of a foreign ballet company in the home of the illustrious banker E. Kahagias, a native of Amphissa, while indifferent to the importance of the Berlin Conference that was taking place. Triantaphillos wrote of his support for the 
country's shoemakers' strike in 1881 thus representing the first pro-labour workers' movement (Stamelos 1982). In the same year an attempt on the life of Triantaphillos was made. Fortunately the shots fired by henchman of the palace (as witnesses verified) in central Athens missed (Korthatos 1983).

In 1880, after leaving this journal in order to publish his own equally satiric and democratic periodical "Mi Hanasi", which later became the newspaper "Acropolis", Gavriialidis was nearly assassinated but managed to ward off the killer, although he was injured and hospitalised, in 1882 (Stamelos 1982).

A year later, Panas's "Hours of Idleness" was reviewed in "Mi Hanesi". The sixth poem from "Hours of Idleness", the title of which is borrowed from Byron, is a scathing diatribe entitled "Disraeli-Efendi" (1876) which is more than eighty lines long of which the last six are:

And since the end justifies the means

We leave the willing tiger to bully us.

Having the conviction that will not delay,

When in the East peace will blossom,

Statues will be raised in memory of us -

Of Disraeli and Midhat to always bless them.

Further poetry of Panas was published under the non de plume "Stamatouli" (Stavropoulou 1987). In 1884, Gavriialidis insisted on the necessity of Greek-Turkish friendship in his newspaper "Acropolis" (Stamelos 1982). In July, Thomas Paschides, who was editor of various journals in Bucharest including both "Decebal, fraternisation of the Anatolian people", and "Iris, the paper of the people of the East", both written in Greek and French, published an article in the "Acropolis" describing his invitation by a Muslim friend to celebrate the Muslim religious festival of Ramadan in Constantinople. He describes how other religious denominations including Christians were invited to celebrate too. Musical concerts in the streets were given by Arabic, Jewish and Armenian musicians. Wandering the streets he heard poetry competitions taking place and he saw a Turkish play being directed by an Armenian (Hadziphotis 1974). While cultural cohesion was apparent in Istanbul, Prince Alexander of Battenberg was responsible for the start of disunity among the indigenous people by invading Serbia, thus breaking the Treaty of Berlin (1881) in 1885.

Writing in "Rambagas", Rokkos Hoidas protested against English interference in its country's national sovereignty of its people who rallied in Athens against Prince Alexander's coup d'état in an attempt to enlarge his territory in Eastern Roumalia, a Turkish province, in 1885. Hoidas pointed out the violence of the English by bringing its fleet into Greek waters. The fleet was led by Prince Alfred, the Duke of Edinburgh. It will be remembered that many Greeks had voted in favour of his becoming king of Greece in 1863 when Othon of Bavaria abdicated after the Cycladic Revolution. 
At this time Hoidas, who became M.P. for Attica, (Loukatos 1984) joined forces with other M.Ps. including A. Oikonomos and Andreas Ringopoulos to form a Democratic Party in support of the working people (Bakounakis 2008). In the same year, Hoidas was injured when an attempt was made on his life (Loukatos 1984).

Announcing Prince Alexander's bellicose stance, the newspaper "Evodmas", edited by Dimitris Kambouroglou, began its first instalment of the republication of "Dar-thula" in September, 1885, from "The Poems of Ossian" (Panas 1885). This poetry served as a moral precept for the Rigas Association in the face of corruption and Western diplomatic machinations which it exposed through its choice of poem. On the front page of "Evdomas", dated 15 September, is an article stressing the necessity of the Greek people to unite according to its great tradition of heroism and altruism. The next column is "Work and Days", which had originated in "Evterpe", edited by Kambouroglou's father. In "Evterpe", January 1850, readers had been exposed to the poetry as shown in the following extract:

"The blond virgin warriors of Morven lamenting hold the sweet lyre of Homer and Sappho and in the place of Greek heroes the melancholy shadows of the heroes of the Bard of Arturus, Fingal and Oscar wander." (Pop [Gorgia] 1850)

In "Evdomas's" next instalment, the paper included a translation by Christos A. Parmenides of "Lascaris" by Abel-Francois Villemain. Parmendides had translated "Hymn to the Sun by Ossian" from "Carthon", published in Athens in 1847 in his anthology "Lascaris and Various Poems" (Parmenides 1847). Parmendides's extract describes how Orthodox Christians were enemies of both Muslims and Catholics in the fifteenth century, which resulted in the war that was still ongoing (Evdomas 1885). For example, in the Cycladic Revolution (1862), the Greek Catholic community fought Greeks of the Orthodox religion in support of the Catholic King Othon (O'Donnell 2014a).

The message of the members of the DEF/Rigas Association was to unite people of all religions and be self-governed throughout Anatolia. Therefore, the importance of the translation of "Dar-thula", which directly follows the extract from "Lascaris", is indicated by the changes that Panas makes at the end of the poem, set in italics. They are reminiscent of lines in the dedicatory poem of the three heroes, at the beginning of the 1862 version so as not to forget those men who sacrificed their lives in the Cycladic Revolution for Greece to become a republic (Panas 1862). Interestingly, in an article, published in "Rambagas", Triantaphillos wrote that the king was not to blame but the people were, as they had not taken advantage of the opportunity of the Cycladic Revolution when they should have removed the rule of a foreign dynasty and established only Greeks with a Greek Constitution (Stamelos 1982). So the republication of "Dar-thula" was to remind Modern Greeks of the importance of valour and sacrifice in the quest for unity, while at the same time demonstrating the 
machinations of Western diplomacy, which was a mask for tyranny. Another translator of "The Poems of Ossian" was the Cycladic writer Dimitris Vikelas.

In the archives of Vikelas is his translation of "The Songs of Selma" (Vikelas n.d.). "The Songs of Selma" were translated, published and distributed throughout the Greek-speaking world to symbolise the futility of war at such times as 1848 (the French Revolution), 1871 (the Paris Communes) and 1882 (the bombing of Alexandria). In 1885, Vikelas gave a talk at the Saint Simon Circle in Paris entitled "The Role and Aspirations of Greece on the Eastern Question". He reminded the audience of Rigas Velestinlis requesting help from Napoleon in support of a movement he was preparing. Vikelas admitted that the Greek Revolution was a revival of Hellenism and not a resurrection of the Byzantine idea. He believed that if there was a true confederation of independent states, united with each other in South Eastern Europe, then the Eastern question would be solved and Europe would no longer have to be concerned. He also stated that Greeks had witnessed a fratricidal war between Serbs and Bulgarians (Vikelas 1885).

Another translator of "The Songs of Selma" was Achilles Paraschos. His epic poem entitled "The Dervishes" more than supports Vikelas's viewpoint:

"The Turkish dervish and Greek worker I reconcile

And I hoist with equal devoutness to the unknown Tombs."

Paraschos wrote "The Dervishes" while living in Taganrog (Tanais in the Hellenistic period) in 1883 (Paraschos 1904).

In November, 1886, the English imposed a blockade. Whenever a blockade occurred, the power of the Greek Parliament was handed over to the king (Philaretos 1897). Byron had translated Rigas's two first verses of his "Battle Cry" (Byron 1919). Panas who had translated Angelos Brofferio's "Greek Scenes" published in the newspaper "Telegraph", included four verses from "Childe Harold's Pilgrimage", which specifically reminds enslaved Greeks under Turkish rule to reawaken their spirit of freedom from their shame of bondage (Stavopoulou 1987).

"Greece! Change thy lords, thy state is still the same; Thy glorious day is o'er, but not thine years of shame." (Byron n.d.)

In order to free themselves they must not rely on foreign help, which will probably re-enslave them but must rise up and conquer the enemy alone. Panas perpetuated the dream. His first translation of "Dar-thula-Lathmon" in 1862 (Panas 1862) demonstrates the treachery through slaughter of the "sons of Usnoth" as they attempted to continue the feats of their cousin, Cuchullin. In "Temora" Book I (1875) Oscar is also determined to fight Cairbar in revenge for his having murdered his friend, Cathol. He is tricked into a combat and dies. He, however, succeeds in killing Cairbar. Cuchullin fought to protect the rightful heir of the land, Cormac II, and dies in battle after being wounded by 
an arrow. Nathos continues to support Cormac II. Cairbar slaughtered both Nathos and Cormac in different battles (Macpherson 1996).

After a Bulgarian victory when the principality of Bulgaria was united with Eastern Roumalia, Prince Ferdinand of Saxe-Coburg, replacing Prince Alexander who abdicated, was crowned King of Bulgaria in August 1887 (Stavrianos 2000).

In December, Panas published "The Death of Cuchullin" in "Evdomas", (Panas 1887) which is prophetic in that it represents both the stranglehold of any unity in the area and the death of its supporters of this organisation, whose moral calibre is equated with the heroes in "The Poems of Ossian" through translation. It is related to the translation of the very first Ossianic poem of an imitation by Byron (Byron 1919), through the lament of Calmar, published in Evterpe in 1850 (Evterpe 1850), when the English imposed its first blockade on Greece (Korthatos 1973b). The "Death of Cuchullan" represents the suppression of the dream - Rigas's dream.

The enemy of the nineteenth century in South Easter Europe and Anatolia were the Cairbars of foreign monarchy. They were determined to take over the land of the Ottoman Empire, a dwindling power. The heroes - scholars who fought with the pen - are members of the Rigas Association (DEF), representatives of the indigenous people seeking peace and unity, through uniting former enemies so as to better defend themselves against the invading tyrants and usurpers. They are compared to Nathos directly, Oscar, Calmar and Cuchullin. They also seek to emulate Fingal. What is again noticeable in the translation is the use of the word "East", which starts with the capital letter thus implying the people or countries east of Europe. For example, Macpherson's line:

"that the sound of the battle may arise with the grey beam of the east."

becomes:

"Countries east of Europe like a great malaise, let the echo of my battle be heard." (Author's translation) (Panas 1887)

Panas explained that "Anatolia", includes Greeks as they are the most diffused of all people in Asia Minor and are thus obliged to commit themselves to the work of joint salvation (Stavropoulou 1987).

The translation of "The Death of Cuchullin" is reminiscent of Rigas's contribution to the implementation of liberty, fraternity and justice:

"Glory will be in my name and my fame will spread into songs. Youth: Let us die! They will say that they have died like the child of Semo [Cuchullin] where glory covers him and his fame will shine for centuries". (Author's translation) (Panas 1887) 
Rigas, the bard whose "Battle Song" was known throughout the zone can be compared to Ossian as he sings about his compatriots who suffered under despotism and usurpation of the land by the enemy. The unity that Rigas endeavoured to instil was similar to that of Fingal: both sought to combat tyranny and invasion while uniting former foes to overthrow the despot.

Those members who strove for unity in the zone continued in their quest including Paschides, who had travelled around Anatolia visiting Alexandria in April, 1882, publishing his experience in his newspaper "Decebal" and in the Rumanian press. Then in Palestine he remarked on the proselytizing by Catholics and Protestants as well as the setting up of a Jewish town in Jerusalem in 1860 by Moses Montefiori and the Allatini brothers of Salonica in the Ottoman Empire (Hadziphotis 1974). Using their own shipping company, the Allatini brothers supplied the British army with goods including wood. As they had purchased forestland on Mount Olympus from the Ottoman government they felled trees for firewood to aid the English army when it invaded Egypt in order to restore the "rightful" Khedive in 1882 (The immortal Allatini Ancestors 2008). The Sultan once again insisted that Halim become the Khedive but had to bow to the desires of Western Powers who insisted on Tewfik, the inexperienced son of Ismail, rather than Halim Pasha, taking the throne (Baring 1908). The leader of the Egyptian Revolution, Ahmad Arabi, an Egyptian Officer and fellah, greatly urged his people petitioning them to show their support for Halim's return as Khedive. Arabi saw Halim as just and honest (Landau 2015). Here is an example of unity sought through making friends of enemies as demonstrated by Fingal, in instilling peace, which Panas implied when comparing Halim to Cathmor in his translation done in Alexandria. As Halim was a colleague of those Alexandrian-Greeks, collaborators of Panas, who had saved his life when he was banished by Ismail in 1866, there can be no doubt that had he been made Khedive, the Democratic Eastern Federation would have received his support, which the Western Powers fought to prevent. Despite further encroachment of the English in taking possession, Paschides continued in his quest to unite the ordinary people in the territory under the Democratic Eastern Federation.

Paschides encouraged the establishing of Greek schools in the area to promote Hellenism with a view to instilling education of the highest calibre of the indigenous people who had lived under Ottoman domination for nearly five centuries. In 1886, Paschides wrote an article, written in French, entitled "The Turkish-Greek Question". It urged the Turks to: reform and unite with the Greek nation; to unite the crescent and the cross; to have done with fanaticism; to adopt Hellenism with the philosophy of Plato and educate the people; to follow Aristotle which Arab scholars had translated in the past as they had also translated the old and new Testament of the Holy Bible from which they had assembled the Koran (Hadziphotis 1974). It is noteworthy that the Ottoman conquest of Arab lands, under the Muslim religion, took away a great deal of what the Arabs had contributed to civilisation and left the land neglected as well as helping to destroy the "free, liberal character of Mohammedianism of the Arabic civilisation" (Thatcher and Schwill 1919). Paschides exhorted that 
the hatred and repugnance among Greeks, Muslim and Jews must cease and be replaced by extending a brotherly hand and that all past grievances of yesteryear must be buried.

In June, 1888, Paschides, who had been residing in Constantinople, was arrested for slander and was imprisoned there. He was later exiled to Fezan in Libya in chains, where he was tortured and then murdered in the desert in May, 1890 (Hadziphotis 1974). Six years previously, Midhat Pasha had been strangled by "Ottoman government agents" in exile in Ta'if in Arabia in 1884 (Zurcher 1984).

Having resigned from politics, Hoidas became joint editor of "Rambagas" (Loukatos 1984). In 1888, Hoidas wrote an article in "Rambagas" reporting on the reunion of the Rigas Association, claiming that the father of these socialist ideas had proclaimed that Greece would be large and was the sister of all people in the Orient who were suffering unjustly and with whom Hoidas hoped would unite to Greece to form a democratic federation (Mavromoustakou 2000). This indicates that the Rigas Association had not disintegrated, as assumed in historical tomes.

Hoidas also wrote articles instilling brotherhood among the people. In October, 1888 he published a letter in "Rambagas", which was considered slanderous. Addressed to the king, the letter read:

"Great Spirit of Byron, who sang and died for Greece O Byron, Byron! Rise from your martyred grave this moment. Come to Athens and Observe the High Commissioner under the ironic name of George Christian, first king of the Greeks! You came from Corfu under the unjust profiteering of your country. You came to the town of Goddess Athina on the revolting and accursed day of 18 October, 1863 transfer" (Loukatos 1984).

To avoid their case being taken up by the Supreme Court and gallantly defended by their colleague, Oikonomos, suddenly the Public Prosecutor assigned the case of "Rambagas" to the Criminal Court in Amphissa in Lamia at the beginning of 1889, which was about two hundred miles away from Athens. The jury was made up of Albanian cattle-breeders, shepherds and farmhands who clearly did not understand Greek. How could they possibly judge a poet and politician on trial for an ideological offence? As a result the verdict imposed the punishment of seven years imprisonment (Prokos 1934).

In the meantime, in January, 1889, Ringopoulos committed suicide. He fell into the sea from a ferry boat. His body was found at Porto Helli (Bakounakis 2008).

In May, 1889, Triantaphillos, a living corpse after bad prison conditions, committed suicide. Gavriilidis wrote no obituary for his former colleague Cleanthes Triantophillos (Stamelos 1982).

Both Gavriilidis and C. Paparringopoulos, the historian, showed cold indifference towards the Serbian founder of the Radical Party and president of the Saint Savvas Association, Svetomir Nikolajevic, when asked for details 
regarding biographical information about Rigas Velestinlis in order to strengthen Serbo-Greek relations. He planned on erecting a statue of Rigas Velestinilis in Belgrade near the castle where he was murdered, which was completed in the same year in 1889 (Hasiotis 2001). From their comportment towards Nikolajevic, it can thus be concluded that Western monarchical rule was in complete control in Greece.

In May, 1890, Rokkos Hoidas, who had been suffering from an injury to the lung caused by a duel fought against the government's tampering with the constitution in favour of monarchy in 1875 and wounded in an attempt on his life ten years later, refusing to sign a grant of official pardon, chose to die in prison in Halkida (Loukatos 1984).

In May, 1890, Panas republished "Lathmon" in "Evdomas" (Panas 1890) as the first lament dedicated to the deaths of his colleagues. Lathmon was an enemy, a foreigner who saw the worthlessness of fighting such valiant and magnanimous fighters - Ossian and Gaul - and Fingal recognises this and rewards him by letting him go free. The reverse happened in Modern Greece where patriots were doomed at the hands of the monarchy and religious differences. For example, Hoidas died in prison in his struggle to support the lower echelons of Greeks and encourage them to become self-governing. The difference in the 1890 translation with that of the 1862 "Lathmon" published in the British Protectorate of Kephalonia (Panas 1862), is the use of the word "Brother" and "Brotherly". Again not only is it a message of learning how to forget the past and to make former foes friends but to instil in the next generation the importance of living in unity. In the same work Panas translates:

"If our ancestors were once enemies and they fought with fury later their children bonded in close friendship and offered each other brotherly dinner" (Panas 1890) (Author's translation)

Macpherson:

"Our fathers contended in battle: but we meet together at the Feast" (Macpherson 1996).

It is reminiscent of Paschides wishing to extend a "brotherly" hand to the Ottomans to bring peace and unity. The word "brother" ("friend" in Machperson) is also similar to that used by Julius Typaldos in his 1856 translation of "Two Nights" from Ossian, during a second blockade by the English (Typaldos 1856).

Other examples of injustices included a third blockade imposed by the British after the Cretan uprising in 1869 (Markopoulos 1968), when the complete "Fingal" was translated into Greek for the first time (Voltairos 1869). Part of "Fingal" had been translated in 1863 during the intermonarchial year after the abdication of Othon (Mavroyiannis 1863), when certain Greeks desired a republic instead of another dynasty. This is apparent in the poem "The Vision of Prince Alfred" by C. Parmenides written in 1864, attached to 
his translation of "Sardanapalos" by Byron. In a note he refers to the arrogance of the British (Parmenides 1865).

In June, 1890, Panas translated "Minvane", the second lament, from the last poem "Berrathon" in "Evdomas" Panas (1890). Minvane, Gaul's sister and daughter of Fingal's former enemy, Morni, and now a friend, laments Ryno, her lover and the son of Fingal, who died in battle against the Danish foe, Swaran. There are several differences in this translation: the first is that blood covering Ryno's armour lying at his feet is described as "covered in blood, loving blood". Macpherson has "The bloody spear of Ryno!" Another word is that of "barbaric" instead of "mossy" to describe where Ryno died. Panas lamenting Paschides's murder, which is emphasised in his translation in a footnote stating that Ryno was murdered, (Macpherson: "died in battle") implicitly refers to Paschides as a son of Fingal (Rigas), who was killed in "barbaric" Ullin i.e. Fez, Barbary (Hadziphotis 1974).

The DEF or the Rigas Association disintegrated with the deaths, either by suicide or murder, of its leaders. Both "The Poems of Ossian" and the writings and legacy of Rigas Velestinlis were almost ignored during the twentieth century (O'Donnell 2014b).

During the latter part of the nineteenth century there was disunity not only among Muslims but also between Catholics as well as Orthodox peoples in the area. There was also disunity among the people of the Orthodox Christian faith themselves, especially after the Bulgarian Schism in 1870 (see Hasiotis 2001). When friends participate in a meal altogether this action of sharing the simple joys of life leads to greater unity. To cement this unity among the different peoples of the area, "The Poems of Ossian", that contain no religion, carry no example of exploitation, retaining a love of Nature, demonstrate the meaning of leadership which sought to defend their land and make friends with their enemies to instil unity. The choice of poem with its chivalric demeanor of its heroes and the timing in connection with historical events demonstrated to the nineteenth century reader an axiomatic truth, which until now, negligence of "The Poems of Ossian" has concealed. Concealment was strengthened when the Turkish language changed from Arabic to Latin script in 1928 and Modern Greek switched from Purist to demotic Greek in 1936. Those certain scholars that attempted to sow the seeds of unity and harmony under the banner of the DEF (Rigas Association) in South Eastern Europe and Anatolia were mourned through both "Lathmon" (republished) and "Minvane", the last translations by Panas.

After translating and publishing "Pope Joan" by E. Mezzabotta (716 pages) in 1895, Panas also committed suicide in September, 1896 in the Foreigners' Hotel in Pireas (Stavropoulou 1987). It could be argued, in view of extreme hostility shown to the supporters of the DEA, whether they did, in fact, "commit suicide". Moreover, they were all adherents of Proudhon who regarded suicide as "fraudulent bankruptcy" (Proudhon 1970).

Should the DEF have succeeded the people of South Eastern Europe and Asia Minor would have been self-sufficient. They would have enjoyed greater autonomy and participation in the organisation of their assets. They would have 
been highly educated through absorbing Hellenic culture as well as inculcating the magnanimity of "The Poems of Ossian". Instead its people, having lived for centuries in harmony, were left to Western monarchy which instigated disunity through gruesome wars resulting in the deracination of its people, which still persist.

\section{References}

Aristidis Oikonomos (n.d.) Retrieved November 24, 2015 from wiki http://bit.ly/ $1 \mathrm{MEPT} 2$.

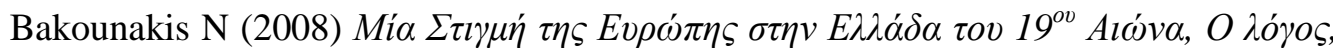

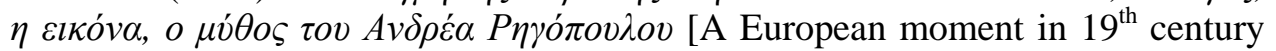
Greece, the word, the picture and the myth of Andreas Ringopoulos] Athens: Polis

Baring E (1908) Modern Egypt. New York: Mackmillan.

Bendigo Advertiser 1879 (Vic.1855-1918) Thursday 26 ${ }^{\text {th }}$ June p.1. Retrieved from http://bit.ly/11Vi51m. [Accessed 4 September 2013].

Bouvier J (1967) Les Rothschilds [The Rotchilds]. Paris: Fayard.

Byron, Lord (1919) The Works of Lord Byron, Volume II. Paris: Gaulon, $2^{\text {nd }}$ edition.

Byron, Lord (n.d.) The Works of Byron with a life and illustrations by William Anderson. Vol. II. Edinburgh: Fullarton.

Cordahi A (2002) "Rhigas Vélestinlis et les transformations juridiques": Rhigas Vélestinlis (1757-1798) Intellectuel et combatant de la liberté [Rhigas Velestinlis and the legal transformations: Rhigas Velestinlis (1757-1798) intellectual and freedom fighter]. Colloque international, 225-256. Paris: UNESCO/Editions DESMOS.

Duff -Gordon L (1969) Letters from Egypt, 1862-1869. London: Routledge and Kegan Paul.

Hasiotis L (2001) The Eastern Federation: "Two Greek Federalist Movements in the $19^{\text {th }}$ Century". Salonica: Vanias.

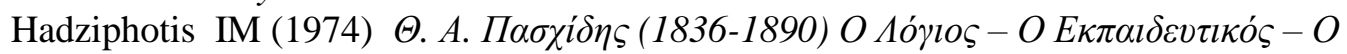

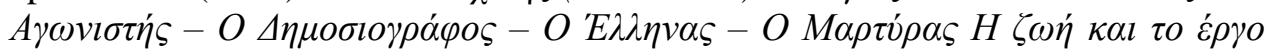

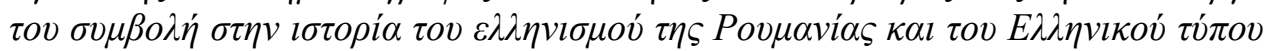
[T. A. Paschides (1836-1890): Scholar - Teacher - Fighter - Journalist - Greek Martyr: His Life and His Work: Symbol of the History of Hellenism in the Rumanian and Greek Press]. Athens: Kritikon Filon.

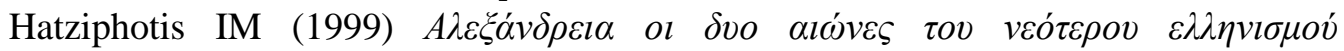
[Alexandria: Two Centuries of Modern Hellenism]. Athens: Ellinika Grammata.

Hekimoglou E (2012) The immortal Allatini Ancestors and Relatives of Noemie Allatini-Bloch (1860-1928). Retrieved from http://bit.ly/1N1aBkd. [Accessed 12 Mars 2014].

Imperial Firman of 27 May 1866 (n.d.) Retrieved from wiki http://bit.ly/1T6vfTy. [2 August 2012].

Ismai'l Pasha (n.d.) Retrieved from wiki http://bit.ly/1HCFfUe. [Accessed 19 November 2015].

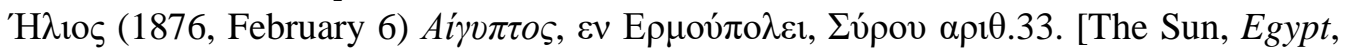
Ermoupolis, Syros 1876 No. 33].

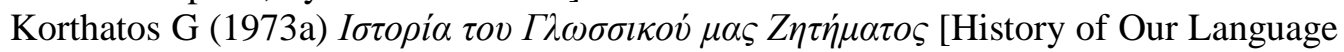
Question]. Athens: Boukoumani. 


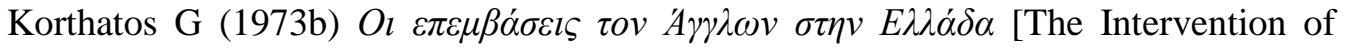
Greece by the English]. Athens: Epikairotita.

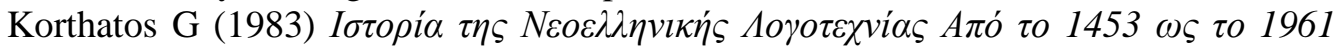
[The History of Modern Greek Literature]. Athens: Epikairotita.

Landau JM (2015) Middle Eastern Themes: Papers in History and Politics. New York, USA: Routledge. Retrieved from http://bit.ly/1IznCzD. [Accessed 12 November 2015].

Lottman HR (1994) La Dynastie Rothschild [The Rothschild Dynasty]. (M Vernon, Trans) Paris: Le Seuil.

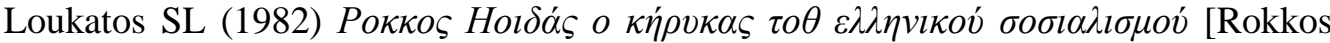
Hoidas: The Advocate of Greek Socialism]. Athens: the Kephalonian and Ithacan Guild of Pireus.

Macpherson J (1996) The Poems of Ossian and Related Works. H Gaskill (Ed) with an Introduction by F Stafford. Edinburgh: Edinburgh University Press.

Markopoulos GJ (1968) King George I and the Expansion of Greece 1875-1881. Balkan Studies 1(9): 21-40.

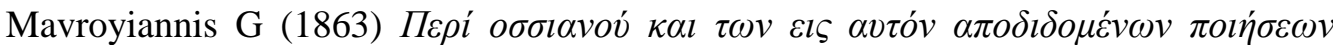
[Ossian and the Poems Attributed to Him]. Chrysalis 1(17): 417-420, 525-531.

Mavromoustakou I (1998) La Constitution de Rhigas: mentions au XIX siècle hellénique [The Constitution of Rhigas: Hellenic references in the XIX century]. Rhigas Velestinilis, (1758-1798) Intellectuel and combattant de la liberté. Colloque international. Paris: UNESCO/Demos.

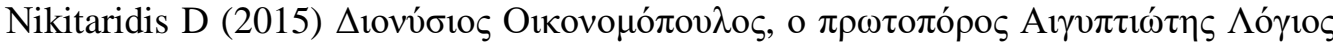

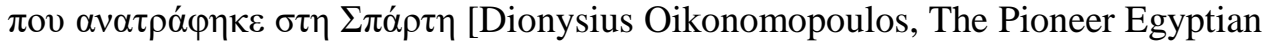

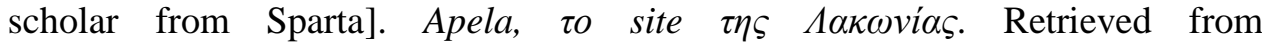
http://bit.ly/1Nv3wOx [Accessed 24 October 2015].

O'Donnell KA (2014a) Nineteenth Century Cycladic Warriors: Celtic Heroes. In Studies on Mediterranean Culture and History: from the Middle Ages through the Early Modern Period SM Oberhelman (Ed), 167-176. Athens: Athens Institute for Education and Research.

O’Donnell KA (2014b) How Twentieth Century Greek Scholars Influenced the Works of Nineteenth Century Greek Translators of "The Poems of Ossian" by James Macpherson. Athens Journal of Philology 1(4): 273 -284.

Panas P (1862) $\Delta \alpha \rho \tau o v ́ \lambda \alpha, \Lambda \alpha \tau \mu o ́ \varsigma, ~ П o \imath \eta ́ \mu \alpha \tau \alpha ~ \tau o v ~ O \sigma \sigma l \alpha v o v ́$ [Dar-thula-Lathmon Poems of Ossian]. Kephalonia: British Protectorate.

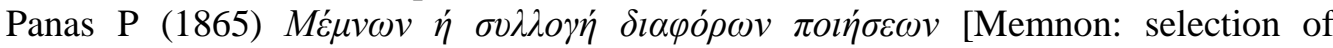
different poems] Alexandria: Nile Press.

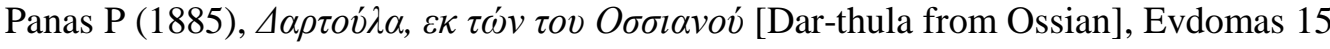
September, 438, 22 September, 451.

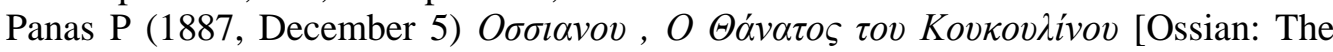
Death of Cuchullin]. Evdomas 4.

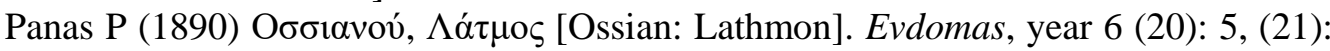
5, (22): 5-6.

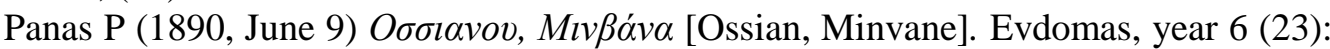
6.

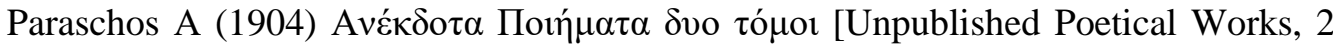
vols]. Athens: Leoni.

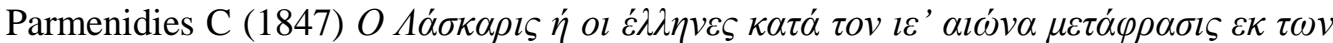

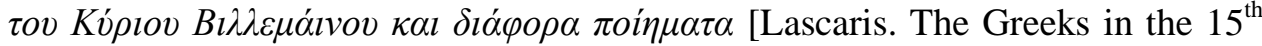
Century by Villemain, and Various Poems]. Athens: Antoniados. 


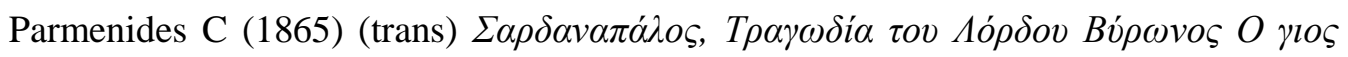

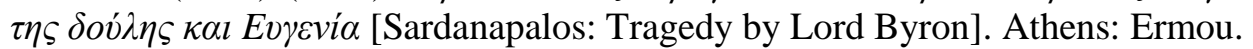

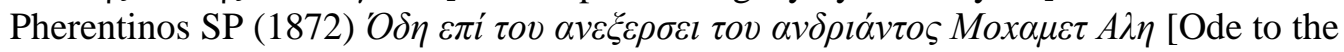
erecting of statue of Mohamid Ali]. Alexandria: Cleopatra.

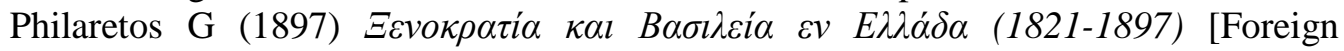
Government and Monarchy in Greece (1821-1897)]. Athens: S. Kousoulinos.

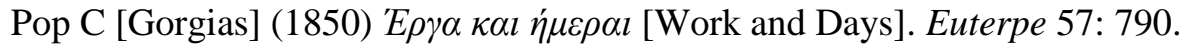

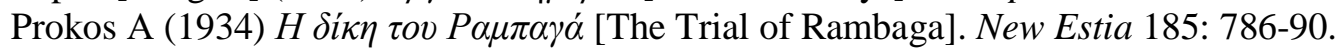

Proudhon PJ (1970) What is Property? An Inquiry into the Principle of Right and of Government with a New Introduction by George Woodock. New York: Dover.

Ross, JA (Duff-Gordon) (1912) The Fourth Generation: Reminiscences. London: Constable \& Company Ltd. Retrieved from http://bit.ly/1jwRXZ6. [Accessed 17 August 2013].

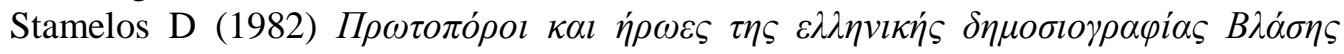

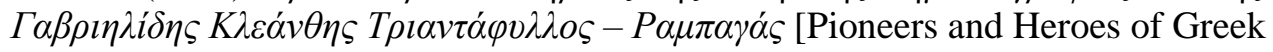
Journalism: Vlassis Gabriilidis, Kleanthis Triantaphillos, Rambagas]. Athens: Glaros.

Stavrianos LS (2000) The Balkans since 1453. London: Hurst and Company.

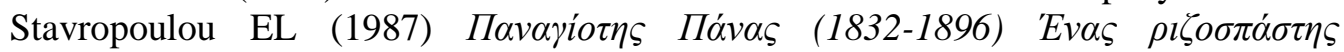

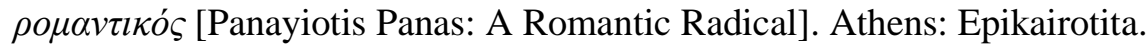

Svolopoulos C (2000) Le concept de "Nation" dans la pensé révolutionnaire de Rhigas Vélestinlis [The concept of "Nation" in the revolutionary thought of Rhigas Velestinlis]. Rhigas Vélestinlis. (1758-1798) Intellectuel and combattant de la liberté. Colloque international, 33-39. Paris: UNESCO/Demos.

Thatcher O, Schwill F (1919) Europe in the Middle Age. London: Murray.

Typaldos J (1953) A $\pi \alpha v \tau \alpha$ Iovגiov Tv́ $\pi \alpha \lambda \delta o \varsigma$ [The Complete Works of Julius Typaldos]. D Conomos (Ed). Athens: Pigis.

Velestinlis R (1994) The Revolutionary Works: Revolutionary Proclamation: Rights of Man: The Constitution: The Battle Cry: The Patriotic Hymn. Athens: Scientific Association.

Vikelas D (n.d.) Ossian: File 785: DB-Album 1-90. Athens: National Library, 149.

Vikelas D (1885) Le Rôle et les Aspirations de la Grèce dans la Question d'Orient [The Role and aspirations of Greece in the Eastern Question]. Paris: Cercle SaintSimon.

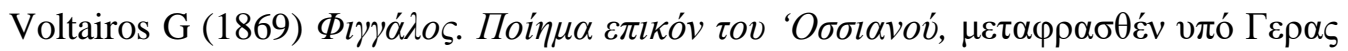

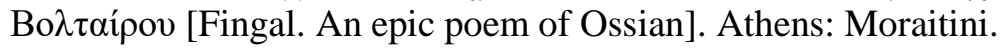

Zurcher E (1984) The Unionist Factor: Role of the Committee of Union and Progress in the Turkish National Movement 1905-1926. Leiden: Brill. ISBN 90-04=072624. 
